\title{
The Effectiveness of Strategic Relationship Marketing: Exploring Relationship Quality towards Customer Loyalty
}

\author{
Song Bee $\operatorname{Lian}^{1} \&$ Liew Chee Yoong ${ }^{1}$ \\ ${ }^{1}$ Faculty of Business, Accounting and Management, SEGi University, Malaysia \\ Correspondence: Song Bee Lian, Faculty of Business, Accounting and Management, SEGi University, No.9, \\ Jalan Teknologi, Taman Sains Selangor, Kota Damansara, PJU5, 47810 Petaling Jaya, Selangor, Malaysia.
}

Received: September 18, 2017

doi:10.5539/ibr.v10n12p159
Accepted: October 16, $2017 \quad$ Online Published: November 8, 2017

URL: https://doi.org/10.5539/ibr.v10n12p159

\begin{abstract}
This study examines customer satisfaction, trust, control mutuality and communication as determinants of relationship quality and customer loyalty in relationship marketing. The study focuses on Malaysian telecommunication industry in the business-to-customer context. The structural equation modelling technique is used to empirically test the proposed hypotheses based on the sample size of 405 customers collected by a questionnaire survey. Trust had the greatest positive influence on relationship quality, followed by satisfaction. Subsequently, there was no significant effect of control mutuality and communication on relationship quality. Customer loyalty was significantly affected by relationship quality. The contribution of this paper is twofold. From a theoretical perspective, the social exchange theory is validated and it offers both a conceptual foundation and empirical-based evaluation of customer loyalty through the context of relationship quality. In the practical perspective, the findings proposed useful information to the telecommunication service providers in developing more effective relationship marketing strategies to build better relationship quality and customer loyalty.
\end{abstract}

Keywords: relationship marketing, relationship quality, customer loyalty, control mutuality

\section{Introduction}

Relationship marketing, defined as "to identify and establish, maintain and enhance relationship with customers and other stakeholders, at a profit so that the objectives of the partners interest are met; this is achieved by a mutual exchange and fulfillment of promise" (Grönroos, 1994). Relationship marketing has emerged in response to the challenging and competitive contemporary business environment. Relationship marketing is widely practice across many business-to-consumer contexts. Companies that strongly adopted and implemented effective relationship marketing have achie ved remarkable organisational benefits in the aspects of greater profitability (San Martin, Jimenez \& Lopez-Catalan, 2016), customer loyalty (Evans and Laskin, 2008; Marzo - Navarro, Pedraj a - Iglesias and Rivera - Torres, 2004), achieving and sustaining competitive advantage (Catalina, 2013). Relationship quality is the key variable to achieve customer loyalty and successful relationship marketing (Prince, Palihawanada, Davies, Winsor, 2016; Jin, Line and Goh, 2013). Relationship quality is a consumer's evaluation of the strength of his or her relationship with the service provider (Crosby, Evans and Cowles, 1990).

The telecommunication industry in Malaysia has achieved remarkable growth and plays an important role in the domestic economy development. According to the Malaysia Communications and Multimedia Commission (MCMC, 2016), there were a total of 43.9 million cellular telephone subscribers or consumers in Malaysia at the end third quarter of 2016. The strong consumer base in the telecommunication industry has resulted in the importance of building effective relationship marketing by the service providers towards their consumers. However, competition between the key telecommunication service providers such as Telekom Malaysia Bhd, Maxis, DiGi, Celcom, and U Mobile has been intensively strong. In the first quarter of 2017, Maxis, DiGi and Celcom continued to see declining number of subscribers, which resulted in their revenue contraction, while ongoing price wars as the players attempted to defend their market share suppressed margins (The Star, 2017). The presence of other competitors in the market have significantly affected the existing long time service providers' market share. The intense price wars between the service providers have caused consumers to opt for better value packages at a lower price and customer loyalty is highly questionable in this case. Hence, the degree of customer loyalty towards the companies are influenced by the relationship quality perceived by the consumers in the aspect of satisfaction, trust, control mutuality and communication (Bojei and Alwie, 2016; Jin et al., 2013; Huang, 2001). 
The primary objectives of this exploratory study are; 1) to investigate the effect of customer satisfaction, trust, control mutuality and communication on relationship quality and 2) to analyse the influence of relationship quality towards customer loyalty. The findings of this research will contribute to managerial and theoretical implications. In the aspect of managerial implications, the research findings will provide valuable information to the telecommunication service providers in developing more effective relationship marketing strategies to build better relationship quality and customer loyalty. In the theoretical perspective, the study has validated the social exchange theory concept. It has shown both a conceptual foundation and empirical-based evaluation of customer loyalty through the context of relationship quality.

\section{Literature Review and Hypotheses Development}

\subsection{Social Exchange Theory}

The Social Exchange Theory is developed to understand the social behavior of humans in economic situations (Homans, 1958). The exchange theory investigates the processes of establishing and sustaining reciprocity in social relations, or the mutual gratifications between individuals (Lee, Mohamad and Ramayah, 2010). Individuals evaluate their reward to cost ratio when deciding whether or not to maintain a relationship. The application of Social Exchange Theory in this study to investigate consumers' evaluation on their benefits to costs represented by relationship quality, and their decision to stay loyal with the service providers.

\subsection{Relationship Quality}

Relationship quality is a consumer's evaluation of the strength of his or her relationship with the service provider (Crosby, Evans and Cowles, 1990). Myhal, Kang and Murphy (2008) highlighted the six dimensions of trust, commitment, satisfaction, minimal opportunism, conflict, and communication in relationship quality. Caceres and Paparoidamis (2007) indicated that relationship quality consists of three dimensions of trust, commitment, and satisfaction. Hon and Grunig (1999a) proposed the six dimensions of trust, control mutuality, satisfaction, commitment, exchange relationships, and communal relationships.

This research focuses on satisfaction, trust, control mutuality and communication as the key dimensions of relationship quality. Hence, this study aim to bridge the research gaps as the four dimensions of satisfaction, trust, control mutuality and communication were not adequately covered by the past literature in the context of relationship quality, and its relationship with customer loyalty in the telecommunication industry.

\subsection{Satisfaction}

Relationship marketing is a long-term approach by focusing on providing superior customer lifetime value and the main success criterion is to develop long-term customer satisfaction (Kotler, Armstrong, Saunders and Wong, 1999). Satisfaction is customer's evaluation of their relationship experience with the service provider. Customer satisfaction was found to be a significant predictor of relationship quality in the Ethiopian mobile telecommunication industry (Negi and Ketema, 2013). Li, Green, Farazmand and Grodzki (2012) reported that relationship quality represented by customer satisfaction has influenced customer loyalty in the context of retail stores' shoppers.

$H_{1} \quad$ There is a positive relationship between satisfaction and relationship quality.

\subsection{Trust}

Trust is the confidence level in the honesty and integrity of the other party (Crosby et al., 1990). Trust also signifies the belief of customer towards their service providers and the service that meets customer needs. According to Cerri (2012), high levels of mutual trust facilitate the effective exchange between the business partners and enhance relationship quality. Trust was found to be important for client-professional relationship quality in the financial planning environment (Hunt, Brimble and Freudenberg, 2011). Chu (2009) asserts that customers' trust is significant in building long-term relationship and achieving customer loyalty. Individual's level of trust is different significantly based on their personal decision-making habits and characteristics.

$\mathrm{H}_{2}$ There is a positive relationship between trust and relationship quality.

\subsection{Control Mutuality}

Control mutuality is the degree to which parties in a relationship are satisfied with the amount of control they have in a relationship (Grunig, 2002). Huang (2001) reported that control mutuality had the greatest influence on successful organisational relationships in South Korea. Botha and Waldt (2010) highlighted that relationship outcomes of control mutuality is important indicators of successful relationships. Hence, their findings were consistent with the earlier findings by Hon and Grunig (1999b) that control mutuality is crucial in the strategies for maintaining organization-public relationships. Steyn (2007) states that stakeholders' involvement in 
decision-making resulted in the stabilization of the organisational relationships.

\section{$\mathrm{H}_{3}$ There is a positive relationship between control mutuality and relationship quality.}

\subsection{Communication}

Communication is one of the important factors in enhancing relationship development and maintenance (Finne and Grönroos, 2009). According to Coviello, Brodie, Danaher and Johnston (2002), communication is determined by the customers' assessment in the aspect of clarity, pleasantness, responsiveness, and language of the service provider. Communication have positive influence towards relationship quality in banking sector (Ruswanti and Lectari, 2016). In a study conducted on the service sector in Malaysia, Bojei and Alwie (2010) reported that communication is the weakest dimension of relationship quality to achieved customer loyalty. Doaei, Razeai and Khajei (2011) reported that interpersonal communication had influenced customer loyalty without relationship quality as mediating role.

\section{$\mathrm{H}_{4}$ There is a positive relationship between communication and relationship quality.}

\subsection{Customer Loyalty}

Customer loyalty is defined as "a deeply held commitment to re-buy or re-patronize a preferred product or service consistently in the future, thereby causing repetitive same-brand or same brandset purchasing, despite situational influences and marketing efforts have the potential to cause switching behaviour" (Oliver, 1999). Hennig-Thurau, Gwinner, and Gremler (2002) assert that customer loyalty is the "primary goal" of relationship marketing. Bojei and Alwie (2010) reported that relationship quality positively influenced the customer loyalty was mainly due strong commitment given by the service provider to the customers. Ruswanti and Lectari (2016) also indicated significant positive relationship between relationship quality and customer loyalty. The service providers have delivered good services which met customer's expectation and goal, and satisfying, subsequently leads to good relational quality and customer loyalty. In contrast, Chen and Myagmarsuren (2011) found that direct relationship does not exist between relationship quality and customer loyalty in telecommunication services. However, it was concluded that relationship quality affect customer loyalty was mediated by relationship value.

$H_{5}$ : There is a positive relationship between relationship quality and customer loyalty.

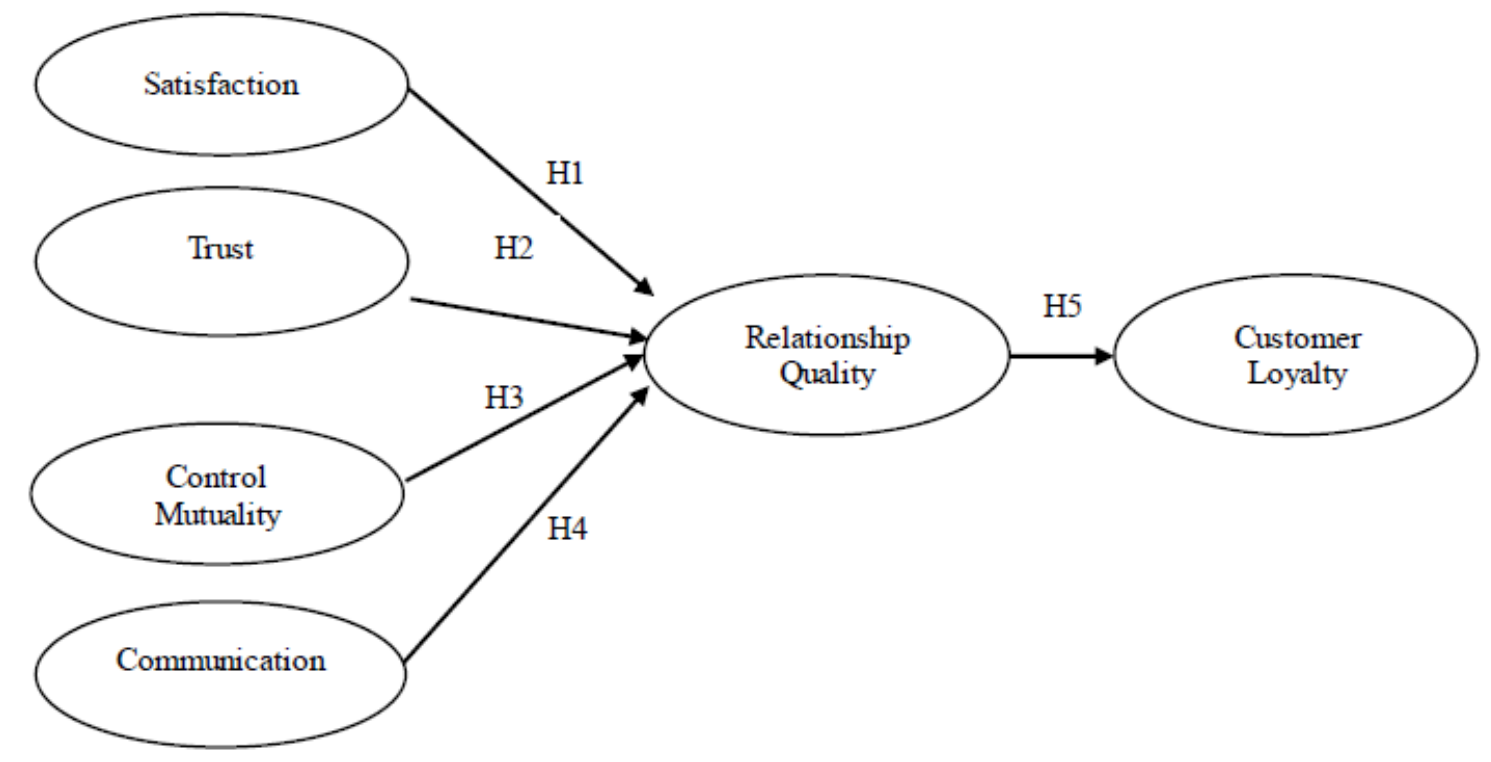

Figure 1. Conceptual framework

\section{Research Methodology}

\subsection{Sampling and Measurement}

This paper is based on data collected from a survey on the existing customers of local telecommunication service providers, namely Maxis, Digi and Celcom, in Kuala Lumpur and Selangor, Malaysia. A sample size of 405 was determined and non-probability convenience sampling method was adopted for this study. Self-administered questionnaires were distributed to the respondents who present at the selected Maxis, Digi and Celcom outlets in 
Kuala Lumpur and Selangor. The survey instrument was designed with 28 items assessed by a six-point Likert scale (1: strongly disagree and 6: strongly agree). The Statistical Package for Social Sciences (SPSS) version 22 was used to perform descriptive analysis, validity and reliability analysis. Followed by, SPSS AMOS version 21 was used to perform the Structural Equation Modeling (SEM) analysis to test the hypotheses.

\subsection{Validity and Reliability Assessment}

The pilot study results indicated the factor loading for all the 28 proposed items is above 0.3 and thereby will be retained (Hair, Black, Babin and Anderson, 2010). The Cronbach's Alpha values for all constructs were above 0.7 which have shown a high level of internal consistency in the data (Pallant, 2007). The Cronbach's Alpha values were 0.951 (Satisfaction), 0.843 (Trust), 0.911 (Control Mutuality), 0.887 (Communications), 0.902 (Relationship Quality) and 0.877 (Customer Loyalty). Table 1 shows the results of Confirmatory Factor Analysis (CFA) for each item in the construct and the reliability test results. The pilot study results showed that all the constructs were valid and reliable for further inferential analyses.

Table 1. CFA results for the measurement model

\begin{tabular}{|c|c|c|c|c|}
\hline Construct & Item & Statement & $\begin{array}{l}\text { Factor } \\
\text { Loading }\end{array}$ & $\begin{array}{l}\text { Cronbach's } \\
\text { Alpha }\end{array}$ \\
\hline \multirow[t]{6}{*}{ Satisfaction } & S1 & I am satisfied with the price offered by my service provider. & .841 & .951 \\
\hline & S2 & I am delighted with the performance of my service provider & .890 & \\
\hline & S3 & The services offered meet my expectations. & .901 & \\
\hline & S4 & $\begin{array}{l}\text { My service provider offers flexible service packages that meet } \\
\text { my needs. }\end{array}$ & .879 & \\
\hline & S5 & $\begin{array}{l}\text { My current service provider could provide me higher } \\
\text { satisfaction than other service providers. }\end{array}$ & .852 & \\
\hline & S6 & Overall, I am satisfied with my service provider. & .881 & \\
\hline \multirow[t]{5}{*}{ Trust } & T1 & My service provide is reliable in providing their services. & .661 & .843 \\
\hline & $\mathrm{T} 2$ & My service provider has high integrity. & .726 & \\
\hline & $\mathrm{T} 3$ & My service provider is trust worthy. & .709 & \\
\hline & $\mathrm{T} 4$ & $\begin{array}{l}\text { My service provider fulfill well their promises (i.e., price } \\
\text { offers, marketing communications, etc). }\end{array}$ & .823 & \\
\hline & T5 & My service provider has a good brand image. & .692 & \\
\hline \multirow[t]{4}{*}{ Control Mutuality } & M1 & $\begin{array}{l}\text { I am always open to give my suggestion for improvement of } \\
\text { the service. }\end{array}$ & .766 & 911 \\
\hline & M2 & My service provider respected customer's feedback. & .935 & \\
\hline & M3 & $\begin{array}{l}\text { My service provider will involve customers in their } \\
\text { promotional activities. }\end{array}$ & .914 & \\
\hline & M4 & $\begin{array}{l}\text { My service provider maintains two ways communication with } \\
\text { the customers. }\end{array}$ & .796 & \\
\hline \multirow[t]{4}{*}{ Communication } & $\mathrm{C} 1$ & $\begin{array}{l}\text { I received regularly updates information on my current } \\
\text { services from my service provider. }\end{array}$ & .707 & .887 \\
\hline & $\mathrm{C} 2$ & The staff are friendly and fulfilled my request at the outlet. & .910 & \\
\hline & $\mathrm{C} 3$ & $\begin{array}{l}\text { Latest promotional information are communicated clearly and } \\
\text { timely manner to the customers. }\end{array}$ & .889 & \\
\hline & $\mathrm{C} 4$ & $\begin{array}{l}\text { My service provider effectively use email and social media to } \\
\text { communicate with customers. }\end{array}$ & .771 & \\
\hline Relationship & Q1 & My service provider is consistent in providing quality service. & .752 & .902 \\
\hline \multirow[t]{4}{*}{ Quality } & Q2 & $\begin{array}{l}\text { My service provider emphasize on mutual relationship with } \\
\text { customers. }\end{array}$ & .787 & \\
\hline & Q3 & $\begin{array}{l}\text { My service provider maintains good quality relationship with } \\
\text { customers. }\end{array}$ & .883 & \\
\hline & Q4 & I received recognition as a loyal customers. & .906 & \\
\hline & Q5 & I am respected as a valuable customers. & .661 & \\
\hline \multirow[t]{4}{*}{ Customer Loyalty } & L1 & I will stay loyal to my current service provider. & .882 & .877 \\
\hline & L2 & I will recommend my service provider to others. & .809 & \\
\hline & L3 & $\begin{array}{l}\text { My relationship with my service provider has a great deal of } \\
\text { personal meaning to me. }\end{array}$ & .798 & \\
\hline & L4 & $\begin{array}{l}\text { I intend to purchase extra other service or package from my } \\
\text { current service provider. }\end{array}$ & .771 & \\
\hline
\end{tabular}

\section{Results}

\subsection{Demographic Profile of the Respondents}

From the total of 405 respondents, majority respondents are female (59\%), followed by male (41\%). As for the respondents' monthly income, 4.7 percent earned less than RM1500, 13.3 percent of the respondents have an income between RM1500- RM3000. Furthermore, 41.4 percent of the respondents have an income between 
RM3000-RM6000 and 31.4 percent of the respondents belong to the income group of RM6000-RM10000. Respondents with an income above RM 10000 comprises 9.2 percent. Majority respondents are Chinese respondents (51.6\%), followed by Malay (26.3\%), Indian (13.5\%) and others (8.6\%). As for the respondents' age, 9.3 percent belong to the age group of 18-20, followed by 25.6 percent under the age group between $21-38$. Majority of 49.1 percent of the respondents under the age group of 39-49, and 16 percent belong to age group of 50 and above.

\subsection{Model Compatibility Testing}

SEM was applied to estimate the relationships between satisfaction, trust, control mutuality, communication, relationship quality, and customer loyalty using the maximum likelihood procedure. The research model has achieved a good fit as shown in Table 2. The Chi-Square value is 902.86 and according to Barrett (2007), chi square probability value greater than 0.05 indicates acceptable model fit. The ratio of $x^{2} / \mathrm{df}$ was 2.66 , lower than the value 3.0, as suggested by Byrne (2001). Incremental fit indices were greater than 0.9, with IFI of 0.93 , CFI of 0.93 and TLI of 0.92. The absolute index with RMSEA of 0.064, achieved lower than 0.8 (Browne and Cudeck 1993).

Table 2. Goodness of Fit

\begin{tabular}{cccc}
\hline Index & Level of Acceptance & Result & Model Evaluation \\
\hline Chi-square & P $>0.05$ & 902.86 & Good \\
Chisq/df & Chi Square / df $<3.0$ & 2.663 & Good \\
RMSEA & RMSEA $<0.08$ & 0.064 & Good \\
IFI & IFI $>0.9$ & 0.930 & Good \\
CFI & CFI $>0.9$ & 0.930 & Good \\
TLI & TLI $>0.9$ & 0.922 & Good \\
\hline
\end{tabular}

The normality assessment was conducted and indicated that the data is normally distributed with value of skewness between -1.0 and 1.0, and kurtosis of between -3.0 and 3.0. Finally, the estimated path coefficients were derived and the research hypotheses were examined.

\subsection{Model Causality Testing}

The final structural model is shown in Figure 2.

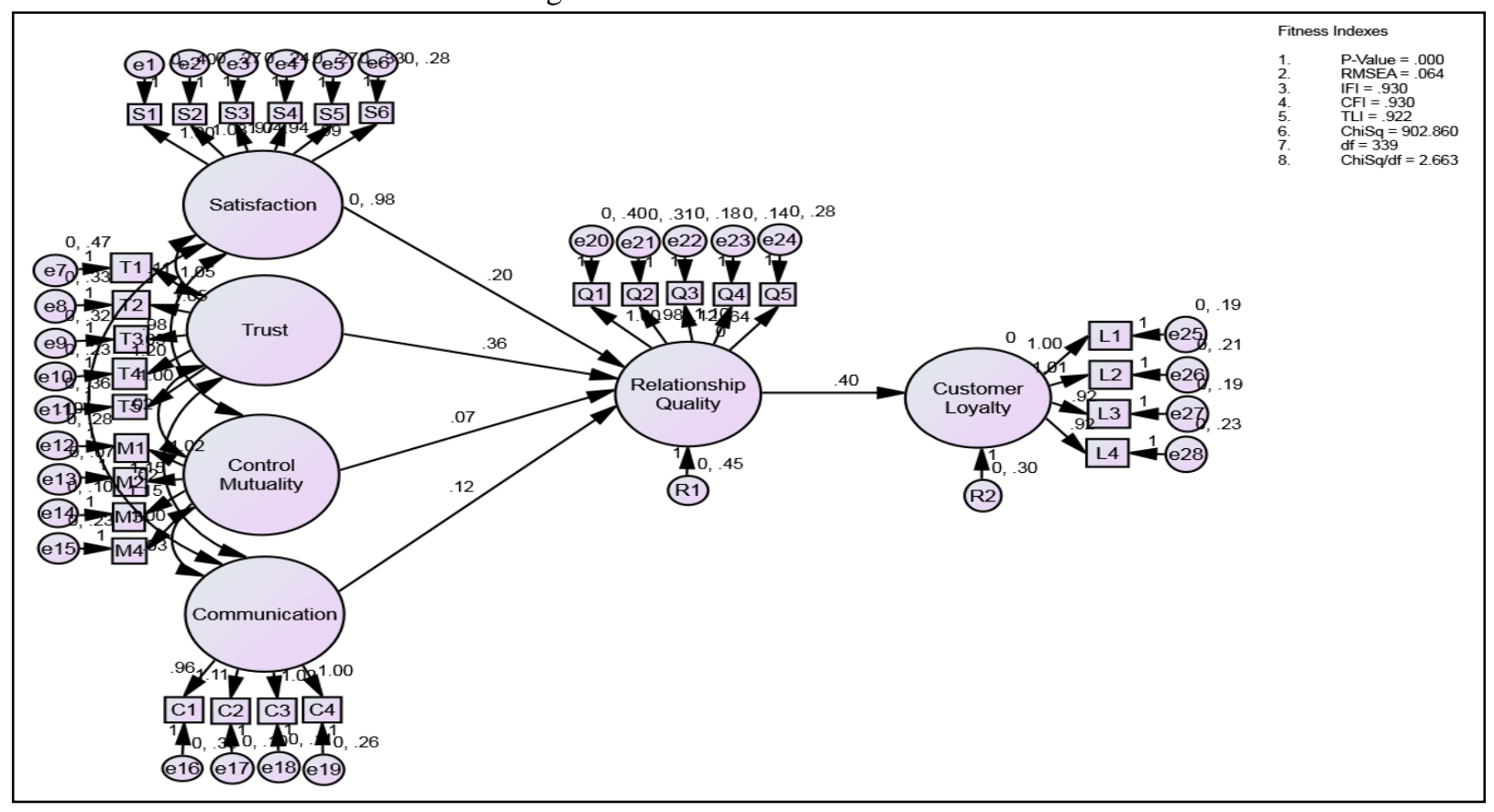

Figure 2. Final Structural Model

The regression weights and probability value which indicates its significance is shown in Table 3 . The results concluded that satisfaction had significant positive effect (0.199) on relationship quality and $\mathrm{H}_{1}$ is accepted. $\mathrm{H}_{2}$ is accepted and trust has significant effect on relationship quality (0.359). The regression coefficient of the relationship between control mutuality and relationship quality is not significant (0.069). The regression coefficient of the relationship between communication and relationship quality is not significant $(0.120)$. As a result, $\mathrm{H}_{3}$ and $\mathrm{H}_{4}$ is rejected. Subsequently, relationship quality had positive effect $(0.403)$ on customer loyalty, 
and $\mathrm{H}_{5}$ is accepted.

Table 3. Regression Weights and the Probability Value which Indicates its Significance

\begin{tabular}{llllllll}
\hline Paths & & & Estimate & S.E. & C.R. & P & Result \\
\hline Relationship quality & $<--$ & Satisfaction & .199 & .040 & 5.039 & $* * *$ & Supported \\
Relationship quality & $<--$ & Trust & .359 & .072 & 4.955 & $* * *$ & Supported \\
Relationship quality & $<--$ & Control Mutuality & .069 & .059 & 1.175 & .240 & Rejected \\
Relationship quality & $<--$ & Communication & .120 & .061 & 1.953 & .051 & Rejected \\
Customer Loyalty & $<--$ & Relationship quality & .403 & .046 & 8.684 & $* * *$ & Supported \\
\hline
\end{tabular}

\section{Discussion and Conclusion}

The social exchange theory is validated through the positive relationship found between relationship quality and customer loyalty. The result of this research found that satisfaction has significant effect on relationship quality. We can conclude that customers are generally satisfied with their current service providers. However, the satisfaction's correlation coefficient value of 0.199 still considered as weak according to "Guilford Rule of Thumb", with $r$ value of below 0.4 (Guilford, 1956). The study also found that trust had the strongest correlation and positively correlated to relationship quality. The results obtained are consistent with the previous studies conducted by Cerri (2012) and Hunt, Brimble and Freudenberg (2011). The findings revealed that for long-term relationship success, relationship quality should focus on increasing customer satisfaction and trust through improvement of service delivery and introduce innovative new services to the customers.

In the price sensitivity consumer market in Malaysia, frequent reward and promotional offers would increase consumers' consumption level and loyalty. Furthermore, the service providers should be more focused in their segment-level strategies by offering different service packages to customers of different segments and value. Customers clearly prefer quality services with fair prices in the competitive market in order to meet their satisfaction and expectations. Attractive packages with better value-adds, for example, offer a bigger data pool to be shared between the principal and supplementary lines. Competition within the telecommunication service providers would have to evolve into greater product differentiation and novelty from the predominant price engagement currently.

Furthermore, the result of this research shown that control mutuality has no significant effect on relationship quality. Customers perceived the service providers have weak involvement of customers in their decision making for service innovation and promotional activities. The degree of control in the relationship that customers have are limited due to commitment and constraint in service contract imposed by the service providers. According to Grönroos and Voima (2013), companies should plan its resources and processes, as well as the competencies to manage them, toward supporting its customers' everyday processes such that the customers' goals are reached in a value-creating manner.

Communication has no significant effect on relationship quality. Although the number of subscribers is large and it can be quite challenging to maintain frequent contact with the customers. The service providers should improve on the credibility, accuracy, adequacy and completeness of the information, and source for more cost effective means of communication via email, sms, personal contact and social network with the customers. More focused and improved communication with the customers would avoid customers from switching to other competitors, and subsequently affect customer loyalty.

This study is confined to the telecommunication industry in Malaysia and limited to the four dimensions of customer satisfaction, trust, control mutuality and communication as determinants of relationship quality. Future studies should explore on other industries and other dimensions of relationship quality such as commitment, benevolence and conflict handling.

\section{References}

Barrett. (2007). Structural equation modelling: Adjudging model fit. Personality and Individual Differences, 42(5), 815-824. https://doi:10.1016/j.paid.2006.09.018

Bojei, J., \& Alwie, A. (2010). The Influence of Relationship Quality on Loyalty in Service Sector. International Journal of Economics and Management, 4(1), 81-100.

Botha, E., \& Van der Waldt, D. L. R. (2010). Relationship antecedents that impact on outcomes of strategic stakeholder alliances. African Journal of Business Management, 4(8), 1629-1638.

Browne, M. W., \& Cudeck, R. (1993). Alternative ways of assessing model fit. In K.A. Bollen \& J. S. Long (Eds.), Testing structural equation models (pp. 136-161). Newbury Park, CA: Sage. 
Byrne, B. M. (2010). Structural equation modeling with AMOS (2nd ed.). New York, NY: Routledge.

Caceres, R. C., \& Paparoidamis, N. G. (2007). Service quality, relationship satisfaction, trust, commitment and business-to-business loyalty. European Journal of Marketing, 41(7), 836-867. https://doi.org/10.1108/03090560710752429

Catalina, C. (2013). Relationship Marketing - Best Practice in the Banking Sector. Amfiteatru Economic, 15(33), 288-300.

Cerri, S. (2012). Exploring Factors Affecting Trust and Relationship Quality in a Supply Chain Context. Journal of Business Quarterly, 4(1), 74-90.

Chen, C. F., \& Myagmarsuren, O. (2011). Brand equity, relationship quality, relationship value, and customer loyalty: Evidence from the telecommunications services. Total Quality Management \& Business Excellence, 22(9), 957-974. https://doi.org/10.1080/14783363.2011.593872

Chu, K. M. (2009). The Construction Model of Customer Trust, Perceived Value and Customer Loyalty. The Journal of American Academy of Business, 14(2), 98-103.

Coviello, N. E., Brodie, R. J., Danaher, P. J., \& Johnston, W. J. (2002). How firms relate to their markets: an empirical examination of contemporary marketing practices. Journal of Marketing, 66(3), 33-46. https://doi.org/10.1509/jmkg.66.3.33.18500

Crosby, L. A., Evans, K. R., \& Cowles, D. (1990). Relationship quality in services selling: An interpersonal influence perspective. The Journal of Marketing, 54(3), 68-81. https://doi.org/10.2307/1251817

Doaei, H., Rezaei, A., \& Khajei, R. (2011). The Impact of Relationship Marketing Tactics on Customer Loyalty:

Evans, J. R., \& Laskin, R. L. (2008). The relationship marketing process: A conceptualization and application. Industrial Marketing Management, 23(5), 439-452. https://doi.org/10.1016/0019-8501(94)90007-8

Finne, ̊., \& Grönroos, C. (2009). Rethinking marketing communication: From integrated marketing communication to relationship communication. Journal Of Marketing Communications, 15(2/3), 179-195. https://doi.org/10.1080/13527260902757654

Grönroos, C. (1994). Quo Vadis, Marketing? To wards a Relationship Marketing Paradigm. Journal of Marketing Management, 10(5), 347-360. https://doi.org/10.1080/0267257X.1994.9964283

Grönroos, C., \& Voima, P. (2013). Critical service logic: implications for value creation and marketing. Journal of the Academy of Marketing Science, 41(2), 133-150. https://doi.org/10.1007/s11747-012-0308-3

Grunig J. E. (2002). Qualitative methods for assessing relationships between organisations and publics. The Institute for Public Relations. Retrieved from http://instituteforpr.com

Guilford, J. P. (1956). Fundamental Statistics in Psychology and Education. New York: McGraw Hill.

Hair, J. F., Black, W. C., Babin, B. J., \& Anderson, R. E. (2010). Multivariate Data Analysis: A global perspective (7th ed.). New Jersey, NJ: Pearson Education Inc.

Hennig-Thurau, T., Gwinner, K. P., \& Gremler, D. D. (2002). Understanding relationship marketing outcomes: an integration of relational benefits and relationship quality. Journal of Servive Research, 4(3), 230-247. https://doi.org/10.1177/1094670502004003006

Homans, G. C. (1958). Social behavior as exchange. American Journal of Sociology, 63(6), 597-606. https://doi.org/10.1086/222355

Hon, L. C., \& Grunig, J. E. (1999a). Guidelines for measuring relationships in public relations. Gainesville, FL: Institute for Public Relations.

Hon, L. C., \& Grunig, J. E. (1999b). Measuring relationships in public relations. Gainesville, FL: Institute for Public Relations.

Huang, Y. H. (2001). OPRA: A cross-cultural, multiple-item scale for measuring organization-public relationships. Journal of Public Relations Research, 13, 61-90. https://doi.org/10.1207/S1532754XJPRR1301_4

Hunt, K., Brimble, M., \& Freudenberg, B. (2011). Determinants of Client-Professional Relationship Quality in the Financial Planning Setting, Australasian Accounting Business and Finance Journal, 5(2), 69-99. https://doi.org/10.2139/ssrn.1867907

Jin, N., Line, N. D., \& Goh, B. (2013). Experiential Value, Relationship Quality, and Customer Loyalty in 
Full-Service Restaurants: The Moderating Role of Gender. Journal of Hospitality Marketing \& Management, 22(7), 679-700. https://doi.org/10.1080/19368623.2013.723799

Kotler, P., Armstrong, G., Saunders, J., \& Wong, V. (1999). Principles of marketing. New Jersey: Prentice-Hall, Upper Saddle River.

Lee, J. W. C., Mohamad, O., \& Ramayah, T. (2010). Outsourcing: is the social exchange theory still relevant in developing countries? Journal of Research in Interactive Marketing, 4(4), 316-345. https://doi.org/10.1108/17505931011092826

Li, M. L., Green, R. D., Farazmand, F. A., \& Grodzki, E. (2012). Customer Loyalty: Influences on Three Types of Retail Stores' Shoppers. International Journal of Management and Marketing Research, 5(1), 1-19.

Marzo - Navarro, M., Pedraja - Iglesias, M., \& Rivera - Torres, M. P. (2004). The benefits of relationship marketing for the consumer and for the fashion retailers. Journal of Fashion Marketing and Management: An International Journal, 8(4), 425-436, https://doi.org/10.1108/13612020410560018

MCMC. (2016). Corporate website. Retrieved from http://www.skmm.gov.my.

Myhal, G. C., Kang, J., \& Murphy, J. A. (2008). Retaining customers through relationship quality: A services business marketing case. Journal of Services Marketing, 22(6), 445-453. https://doi.org/10.1108/08876040810901864

Negi, R., \& Ketema, E. (2013). Customer - perceived relationship quality and satisfaction: A case of Ethiopian Telecommunication Corporation. African Journal of Economic and Management Studies, 4(1), 109-121. https://doi.org/10.1108/20400701311303186

Oliver, R. L. (1999). Whence customer loyalty? Journal of Marketing, 63(4), 33-44. https://doi.org/10.2307/1252099

Pallant, J. (2007). SPSS Survival Manual. Maidenhead: Open University Press.

Prince, M., Palihawadana, D., Davies, M. A. P., \& Winsor, R. D. (2016) An Integrative Framework of BuyerSupplier Negative Relationship Quality and Dysfunctional Interfirm Conflict. Journal of Business-to-Business Marketing, 23(3), 221-234. https://doi.org/10.1080/1051712X.2016.1215741

Ruswanti, E., \& Lestari, W. P. (2016). The Effect of Relationship Marketing towards Customers' Loyalty Mediated by Relationship Quality (Case Study in Priority Bank in Niaga). DeReMa (Development Research of Management): Jurnal Manajemen, 11(2), 191-211. https://doi.org/10.19166/derema.v11i2.230

San Martin, S., Jimenez, N. H., \& Lopez-Catalan, B. (2016). The firms benefits of mobile CRM from the relationship marketing approach and the TOE model. Spanish Journal of Marketing, 20(1), 18-29. https://doi.org/10.1016/j.reimke.2015.07.001

Steyn, B. (2007). Contribution of public relations to organisational strategy formulation. In Toth, E.L. (Eds.), The future of excellence in public relations and communication management: Challenges for the next generation (pp.137-172). New Jersey, USA: Lawrence Erlbaum Associates.

The Mediation Role of Relationship Quality. International Journal of Business Administration, 2(3), 83-93. https://doi.org/10.5430/ijba.v2n3p83

The Star (2017, June 24). Growth challenges of telcos. Retrieved from http://www.thestar.com.my/business/business-news/2017/06/24/growth-challenges-of-telcos/

\section{Copyrights}

Copyright for this article is retained by the author(s), with first publication rights granted to the journal.

This is an open-access article distributed under the terms and conditions of the Creative Commons Attribution license (http://creativecommons.org/licenses/by/4.0/). 